\title{
Perception of Territorial Actors on Their Roles in the Implementation of Planning Tools in Mali
}

\author{
Abdoulaye Sanogo \\ Management Science, Institute of University Pedagogy (IPU), Bamako, Mali \\ Email: sanogo.abdoulaye@yahoo.fr
}

How to cite this paper: Sanogo, A. (2021). Perception of Territorial Actors on Their Roles in the Implementation of Planning Tools in Mali. Advances in Applied Sociology, 11, 26-33.

https://doi.org/10.4236/aasoci.2021.111003

Received: December 20, 2020

Accepted: January 23, 2021

Published: January 26, 2021

Copyright $\odot 2021$ by author(s) and Scientific Research Publishing Inc. This work is licensed under the Creative Commons Attribution International License (CC BY 4.0).

http://creativecommons.org/licenses/by/4.0/

(c) (i) Open Access

\begin{abstract}
Many actors intervene in the territory and often the divergence of points of view and interests oppose them. This can generate conflicts of interest, prerogatives and others. To better understand the actions taken by the various players in the area, we felt it necessary to bring some of them closer together. These are academics, senior officials working in the field of regional planning, political and administrative authorities, etc. The opinions of these actors will allow us to understand their roles in the implementation of planning tools in Mali by general and certain municipalities in particular. The opinions focused on the role of the actors in the implementation of planning tools. Indeed, this research allowed us to identify the actors and group them according to their center of interest, before seeking to understand their roles in the implementation of planning tools. The results obtained relate to the following elements: 1) territorial actors, each at their own level, do not properly play their roles; 2) the territorial actors do not consult each other before taking action; 3 ) the interests of groups take precedence over the general interest of the entire population of the territory concerned; 4) actors are excluded from decision-making.
\end{abstract}

\section{Keywords}

Territorial Actors, Planning Tools, Perception of Stakeholders, Governance of Territories

\section{Introduction}

The surveys carried out among the actors (authorities, decentralized services, resource persons, population, and other actors) concerned a total of 235 people. They were carried out in the region of Sikasso and in the District of Bamako with regard to specialists and resource persons.

Several territorial players are involved in the implementation of planning 
tools. These are the state, local authorities, civil society organizations and the private sector.

However, we are going to group the results of these surveys into three categories: opinions of specialists, municipal authorities and populations.

These actors often act without consulting each other and without taking into account the interests of others. As a result, the effective and efficient implementation of planning tools is compromised.

Projects are initiated and abandoned by the force of opposition. The locations of equipment/infrastructure are contested and the real needs of the populations are often ignored. This ensures that efforts are dispersed and very often a group of actors do not properly play their role out of ignorance or for political and social considerations.

The interactions of uncoordinated territorial actors do not contribute to the implementation of planning tools, essential to ensure the balanced and sustainable development of our territories.

To understand the actions of these territorial actors, we have initiated this article which aims to:

- Identify the role of territorial actors in the implementation of planning tools;

- Understand the level of involvement of these actors in the implementation of planning tools.

Located in the interior of West Africa, Mali, with its $1,241,238 \mathrm{~km}^{2}$, is the largest state in West Africa after Niger (Ministry of Regional Planning and Population, 2016). Its population, which is growing at an accelerated rate, has grown from 14,528,662 inhabitants in 2009 (National Institute of Statistics, 2009) to 19,419,003 inhabitants in 2018 (National Directorate of Population Projection, 2018) and 19,972,000 inhabitants in 2019 (National Directorate of Population Projection, 2019). It is a low-density country with around 15.6 inhabitants per $\mathrm{km}^{2}$ (National Directorate of Population Projection, 2019).

More than 2/3 of the Malian territory is desert. It is severely confronted with the harmful effects of climate change: recurrent droughts, floods, desertification, desertization, extreme poverty, food insecurity, epidemics and other avatars.

The Circle of Koutiala, located in the region of Sikasso, the third administrative region of Mali, is bordered to the north by the Circle of San, to the northwest by the Circle of Bla, to the southwest by the Circle of Dioila, to the south by the Circle of Sikasso and the Republic of Burkina Faso and in the East by the Circle of Yorosso. It covers an area of $8740 \mathrm{~km}^{2}$ or $12.17 \%$ of the total area of the Region and $0.7 \%$ of that of Mali (Office of Koutiala Circle Council, 2018). The Circle of Koutiala is made up of 35 rural common and one urban common for a total of 262 villages/hamlets (Office of Koutiala Circle Council, 2018). In 2009, the population of the Circle of Koutiala was estimated at nearly 580,453 inhabitants (National Institute of Statistics, 2009).

\section{Materials and Methods}

It consisted of a documentary search. The documents consulted are, national 
documents (the report of the Ségou workshop on the renewal of planning in 1996, the five-year plans from 1961 to 1991, National Policies (transversal or sectoral), reports and other sectoral documents, dissertations and theses.

Following this documentary research, we carried out a data collection initiated after sampling. The collection concerned 10 municipalities (Koutiala, Sincina, M’pèssoba, Fagui, Zangasso, N’Goutjina, Koningué, Nafanga, Kapala, Sinkolo) and 200 people (Bamako, Sikasso, Kati) (Communal Councils of the Circle of Koutiala, 2017).

During this collection, we used two tools. It's about:

- The questionnaire;

- The interview guide.

Of the 200 people to be surveyed in the municipalities, 98 people or $49 \%$ completed the questionnaire completely, 50 people or $25 \%$ partially completed the questionnaire by answering certain questions with a "nothing to report" and 52 people or $26 \% \mathrm{n}$ did not give any answers, anything that they motivated by ignorance of the subject and despite our attempts to explain, they preferred to direct us towards the Mayors, the Secretaries General, the notabilities, the leaders of the youth organizations and women

The entry was made with Microsoft Word. As for the tables and graphs, they were drawn up with Microsoft Excel.

Finally SPSS was used to do some analyzes.

\section{The Results}

\subsection{The Opinions of Specialists}

Through an interview guide annexed to this document, we have gathered the opinion of certain specialists (21 in total) on the role of territorial actors responsible for the implementation of planning tools in Mali, particularly in the municipalities surveyed.

To do this, we brought together actors evolving or having evolved in the planning system in Mali.

Most of the specialists interviewed believe that the actors responsible for implementing the planning tools are not playing their roles properly. These are the State, local authorities, civil society, the private sector and development partners.

In the implementation of planning tools, a firm will on the part of the players is far from being observed, which largely explains the failure to respect the guidelines of these tools and the failure to achieve the objectives set.

Mali faces a lack of human resources responsible for strategic planning issues.

This partly explains the inconsistency of actions and the dysfunction of the operational mechanisms applied by the various institutional actors (Government, local authorities, civil society and partners).

The lack of awareness of the importance of planning tools by certain actors, especially those of local authorities is also a finding underlined by experts. Thus, making planning tools instruments of development is not in their culture. 
Beyond that, some of these actors pursue political objectives to the detriment of balanced development and the general interest.

The multiplicity of actors and decision-making bodies, the insufficiency of financial resources are all handicapping factors for the coherence of the actions and the effectiveness of the interventions of the actors who evolve in difficult working conditions. To this end, it is essential to:

- Build the capacities of actors;

- Energize the structures/bodies in charge of planning;

- Strengthen communication around planning tools ...

The main actors (owners, contractors, delegates, etc.) must also observe effective and efficient coordination and monitoring and evaluation. See Table 1 for more detail.

\subsection{The Perception of Municipal Authorities}

This involved talks mainly with the municipal authorities (Mayors, Secretaries General) who are responsible for the development and implementation of planning tools in the 10 target municipalities. In some municipalities, representatives of the state (sub-prefects) have also been brought together, although most of them only intervene when it comes to the budget or calling technical services to a meeting.

According to the representatives of the State brought together, their advisory support is seldom requested by the Mayors who think that they are not accountable to the Sub-prefects who must be satisfied with the establishment of identity cards and validation of the budget of the common authority.

To this end, our interlocutors believe that the State is not making enough efforts to allow the municipalities to meet the real needs of the populations. It continues to keep a lot of skills and resources, despite the requirements of the skills transfer texts.

The municipalities are responsible for collecting the most difficult taxes to collect and do not have access to significant amounts at the counters of the National Agency for the Investment of Territorial Collectivities (ANICT).

As far as development partners are concerned, their interventions are considered ad hoc, inconsistent and poorly adapted to real development needs.

These mainly invest in qualified social projects that are not structuring and sometimes unfinished. This does not allow to boost local economies.

Table 1. Opinion of specialists.

\begin{tabular}{cccc}
\hline \multirow{2}{*}{ Heading } & \multicolumn{3}{c}{ Infrastructure/equipment } \\
\cline { 2 - 4 } & Number & Rate & Observation \\
\hline $\begin{array}{c}\text { Territorial actors properly } \\
\text { play their role }\end{array}$ & 0 & 0 & $\begin{array}{c}\text { Low commitment of territorial } \\
\text { actors for the implementation } \\
\text { of planning tools }\end{array}$ \\
$\begin{array}{c}\text { Territorial actors do not } \\
\text { properly play their role }\end{array}$ & 25 & 100 & \\
Total & 25 & 100 & \\
\hline
\end{tabular}

Source: doctoral student survey results. 
The contribution of the population and the private sector is considered insufficient by the municipal authorities to undertake large-scale actions in the municipalities, which in the majority are struggling to meet their operating needs, let alone make investments.

Regarding their own roles, the communal authorities have said they are doing their best. However, when referring to the comments of specialists and technical services, they are indexed as being the main sources of problems in coordinating development actions in the municipalities. The municipal authorities seem to be the weak link in the chain. See Table 2 for more detail.

\subsection{People's Perception}

After having administered two interview guides, one with specialists/experts working in technical services, in the world of university, research and consulting and the other with municipal authorities, we administered a questionnaire to the populations. A total of 200 people were surveyed, or 20 people per target municipality.

However, should it be pointed out, the surveys did not give the desired results, because of the 200 people $25 \%$ of the people surveyed preferred to give partial information and $26 \%$ of the people surveyed did not complete the questionnaire at all. .

They implied that they do not know anything about planning and that they are unable to provide correct answers to the questions relating to the actors responsible for the implementation of planning tools;

Regarding the implementation of planning tools, the majority (59\%) of the populations surveyed said they did not know what to do, but they suggested that they always responded to requests from the authorities through:

Participation in public works (maintenance of rural roads and public spaces);

Participation in meetings organized by village councils;

The purchase of vignettes...

However, $15 \%$ of respondents think that the population is not playing its role properly in the implementation of planning tools. Reason, populations do not fulfill their role of citizen control and many of them do not pay municipal taxes/fees.

Table 2. Opinion the authorities.

\begin{tabular}{cccc}
\hline & \multicolumn{3}{c}{ Infrastructure/equipment } \\
\cline { 2 - 4 } Heading & Number & Rate & Observation \\
\hline $\begin{array}{c}\text { The municipalities } \\
\text { assume their role }\end{array}$ & 0 & 0 & The transfer of skills and resources must \\
$\begin{array}{c}\text { The other actors do } \\
\text { not fulfill their role }\end{array}$ & 10 & 100 & $\begin{array}{c}\text { beffective to allow municipal } \\
\text { acto accomplish their mission }\end{array}$ \\
Total & 10 & 100 & \\
\hline
\end{tabular}

Source: doctoral student survey results. 
Other people surveyed (26\%) preferred to remain silent on the pretext that they did not understand the subject.

Regarding the other actors (State, Territorial Communities), $85 \%$ of our respondents think that they do not make enough effort to involve the population in the implementation of planning tools. They are taxed by our interlocutors of actors having little regard for the population.

In addition, our respondents deplored the weight of political, social and corruption considerations in the management of public affairs.

With regard to development partners, they have been described as peddling actors with projects preconceived elsewhere and unsuited to local realities. Indeed, one thing is certain, the success of the implementation of planning tools depends on the level of involvement of the populations and the rate of collection of taxes deemed insufficient to ensure effective implementation of planning tools. In this regard, many people recognize that they are not properly fulfilling their duty to pay taxes.

The municipal tax collection rates rarely exceed $20 \%$ in the municipalities surveyed. Hence the need to undertake awareness-raising and capacity-building actions for all the actors responsible for implementing planning tools.

In short, it is urgent to review the strategies adopted for the involvement of the populations in the implementation of planning tools and the approaches to collaboration with them. See Table 3 for more details.

\section{Discussion of the Results}

From the analysis of the results of the interviews and surveys, we can say that the actors responsible for the implementation of planning tools do not fully play their roles and do not collaborate enough.

The involvement of the populations in the process of developing and implementing planning tools is reduced to simple consultation.

It also emerges that the territorial aspect is not adequately taken into account in development actions that operate under political influence and without reference to planning tools. More concretely, the municipalities do not have quality and long-term planning tools (Tables).

Table 3. Public opinion.

\begin{tabular}{cccc}
\hline Heading & \multicolumn{3}{c}{ Infrastructure/equipment } \\
\cline { 2 - 4 } & Number & Rate & Observation \\
\hline $\begin{array}{c}\text { The populations play their } \\
\text { role appropriately }\end{array}$ & 118 & 59 & \\
$\begin{array}{c}\text { Populations are not playing } \\
\text { their role properly }\end{array}$ & 30 & 15 & $\begin{array}{c}\text { Citizen watch is not } \\
\text { properly ensured. }\end{array}$ \\
No opinion & 52 & 26 & \\
Total & 200 & 100 & \\
\hline
\end{tabular}

Source: doctoral student survey results. 
Inter-communality, which should allow development actions to be included in a global framework of intervention, does not work well in the municipalities surveyed.

Every man for himself who seems to have gained ground does not allow good coordination of development actions in the said municipalities where the rates of collection of taxes and duties are low ( $20 \%$ on average).

Fear of offending the sensitivities of voters prevents elected officials from using the means provided in this area.

As regards the customary or traditional authorities, they are more and more isolated and are no longer listened to as before. This is why most of them ride for political power or swear by individual interest.

The governance of the territories does not operate in a transparent manner, the choices made are always subjective and do not respect the standards and procedures laid down by the texts.

Not to mention the lack of awareness of the importance of planning tools which constitutes a blocking factor with regard to the distribution of infrastructure/equipment and the promotion of local initiatives. Thus, we are witnessing the execution in our municipalities of several non-program projects developed elsewhere.

The dysfunction of monitoring and evaluation mechanisms and the non-evaluation of the impacts of planning tools demonstrate to what extent the implementation of planning tools is relegated to the background in our municipalities where the palpable and the urgency have taken precedence.

The result does not matter much in these municipalities. The main thing is to prove to the voters that we are working at the Town Hall where no place seems to be given to the notions of harmonious and sustainable development, good governance, and the general interest.

Finally, we can say that development projects do not meet the real needs of the populations, because they are poorly designed, do not fit into the long term or within a framework of spatial coherence.

\section{Conclusion}

The transversality of planning requires the establishment of consensual and inclusive instruments. The multi-actor and scale character requires close collaboration between actors and a simple institutional anchoring adapted to all decision-making levels.

Ensuring consistency and compliance with planning tools necessarily requires the establishment of coordination, consistency, arbitration and consultation bodies.

First of all, it is necessary to have political instruments. As such, we propose to review the current system. Thus, at the national level, we are going to have a single political body called the Superior Council for Planning, Development and Territorial Development. 
The Superior Planning Council should have regional branches. Thus, the Regional Planning Council should be placed under the chairmanship of the Regional Governor, assisted by the President of the Regional Assembly. It must play the same roles as the Superior Planning Council and will only be interested in matters within its territorial jurisdiction or any other subject submitted for opinion by the Superior Planning Council.

With regard to secondary tools, the opinion of the Superior Council is not necessary for their implementation, which must be authorized by other bodies placed under its supervision.

\section{Conflicts of Interest}

The author declares no conflicts of interest regarding the publication of this paper.

\section{References}

Communal Councils of the Circle of Koutiala (2017). Development Programs of the Communes of the Circle of Koutiala.

Ministry of Regional Planning and Population (2016). National Land Use Planning Policy. Bamako, 41 pages + annex.

National Directorate of Population Projection (2018). Demographic Projection of Mali: Office of DNP.

National Directorate of Population PROJECTION (2019). Demographic Projection of Mali: Office of DNP Report 2019.

National Institute of Statistics (2009). Theme 2 State and Structure of the Population: Office of Census.

Office of Koutiala Circle Council (2018). Circle Monograph Report: Office of Koutiala Circle Council. 